\title{
Potassium Channel Regulation in Schwann Cells During Early Developmental Myelinogenesis
}

\author{
G. F. Wilson ${ }^{\text {}}$ and S. Y. Chiu \\ 'Department of Neurophysiology, and ${ }^{2}$ Neuroscience Training Program, University of Wisconsin, Madison, \\ Wisconsin 53706
}

The presence of neuronal-like, voltage-gated ion channels on glia has raised questions concerning their physiological roles. Insights into glial channel function can be gained by examining regulation of channel expression during axoglial interactions. We examine the regulation of Schwann cell potassium channels in developing sciatic nerves of newborn rats when myelin is first laid down. During the initial postnatal week, cell-attached patch-clamp recordings at soma of Schwann cells with visible myelin revealed an inward rectifying potassium channel $\left(\mathrm{K}_{\mathrm{IR}}\right)$, to date described only in CNS glia but not Schwann cells, as well as an outward potassium channel $\left(K_{0}\right)$. Around the resting potential, the $K_{0}$ channel is virtually closed, while the $K_{\mathrm{IR}}$ channel appears maximally open. Compared with the $K_{\mathrm{O}}$ channel, the $K_{\mathrm{IR}}$ channel is blocked by low concentrations of $\mathrm{Cs}^{+}$and exhibits higher sensitivity to 4-aminopyridine (4AP). Further, the $K_{1 \mathrm{r}}$ channel appears similar to other mammalian inward rectifiers and rectification depends, in part, on cytoplasmic $\mathbf{M g}^{2+}$.

Channel regulation bears an interesting relation to early myelination: as the average number of myelin lamellae increases from 6 to 21 from day 2 to day 8 , currents decrease by $80-90 \%$. The reduction in $K_{\circ}$ current also parallels the known decrease in proliferation of Schwann cells as they are being committed to myelination, supporting the recently proposed notion of a functional link between potassium channels and proliferation. The $K_{\mathrm{I}}$ channels, by virtue of being open at the resting potential, may play a role in buffering activity-dependent $K^{+}$accumulation during early myelin formation. The subsequent reduction in somal channel density may parallel a diminished need for $\mathrm{K}^{+}$buffering as electrogenesis is restricted to nodal regions.

Schwann cells insulate axons with myelin and traditionally have been regarded as passive cells with no direct role in the electrogenesis of peripheral nerves. However, patch-clamp recordings recently have provided evidence for the existence of neuronallike, voltagc-gated ion channcls in mammalian Schwann cells

\footnotetext{
Received Aug. 24, 1989; revised Nov. 15, 1989; accepted Nov. 24, 1989.

We wish to thank Fred Sigworth for least-squares fit software for duration histograms. We further thank Lisa Henderson for help in the EM studies, and Carol Dizack and Terry Stewart for help in illustration and photography. This work was supported in part by grants NS-23375 from the USPHS, RG-1839 from the U.S. National Multiple Sclerosis Society, and a Pew Scholar award in the Biomedical Sciences to S.Y.C.

Correspondence should be addressed to S. Y. Chiu, Department of Neurophysiology, University of Wisconsin, 283 Medical Sciences Building, 1300 University Avenue, Madison WI 53706.

Copyright (C) 1990 Society for Neuroscience $0270-6474 / 90 / 051615-11 \$ 02.00 / 0$
}

under cultured conditions (Chiu et al., 1984; Gray and Ritchie, 1985; Shrager et al., 1985), hinting that the Schwann cell's role may be more active than the traditional view implies. Already, accumulating evidence has revealed an interesting relation between channel expression and cell phenotype. Specifically, in adult sciatic nerves of rabbit, ionic currents can be detected in whole-cell recordings from the soma of nonmyelinating, but not myelinating cells (Chiu, 1987), suggesting that channel expression is functionally specialized. CNS glia also appear to express different channel populations according to their specific identity (Barres et al., 1988).

During the first week after birth, in both rats and mice, Schwann cells and axons undergo a series of rapid morphological changes which largely determine the constituency of adult nerves (Friede and Samorajski, 1968; Webster and Favilla, 1984). First, Schwann cells separate from fetal bundles and sort out their relation with future axons. Second, there is a phase of proliferation which is believed to subside as myelination commences. Since both the proliferative and myelinogenic behaviors of Schwann cells appear to be determined, in part, by axons (Wood and Bunge, 1975; Aguayo et al., 1976; Wcinberg and Spcncer, 1976), one wonders whether the phenotype specific expression of ion channels also is influenced by axon association or predetermined at birth. Sontheimer et al. (1989) observe that, in CNS oligodendrocytes, voltage-gated currents develop independent of axon association. However, Bray et al. (1975) suggest that Schwann cells appear more dependent on axons than oligodendrocytes during differentiation.

To address this issue, we used the patch-clamp to examine whether a corresponding change in ion channel expression occurs in normally developing Schwann cells. We focused only on voltage-gated potassium channels in cells visibly beginning to elaborate myelin and found not only an outward rectifying potassium channel which resembles that described in previous studies of Schwann cells (Chiu et al., 1984; Shrager et al., 1985; Chiu, 1987, 1988; Chiu and Wilson, 1989), but also an inward rectifying potassium channel which previously has not becn described for Schwann cells. Both channels disappear from the soma as myelination proceeds. These channels may modulate the proliferative properties of Schwann cells, as well as buffer any activity-dependent accumulation of $\mathrm{K}^{+}$in immature nerves.

\section{Materials and Methods}

Cell preparation

Schwann cells from sciatic nerves of rat (Sprague-Dawley; postnatal days $1-8$ and 45 ) were isolated acutely for patch-clamp studies by collagenase treatment $\left(0.3 \%\right.$, Type I, Cooper Biomedical; $15 \mathrm{~min}$ at $37^{\circ} \mathrm{C}$ 
for postnatal days $1-8,45 \mathrm{~min}$ for postnatal day 45 ) as described previously (Chiu, 1987).

\section{Electrophysiology}

Patch-clamp recordings of single channels in cell-attached, inside-out, and outside-out configurations (Hamill et al., 1981) were done using a List EPC-7 amplifier on Schwann cells $1-4 \mathrm{hr}$ after isolation. Pipette junction potentials were nulled immediately prior to seal formation.

\section{Voltage-ramp experiments}

The membrane potential was ramped linearly between 2 potentials at a speed of $0.83 \mathrm{~V} / \mathrm{sec}$ preceded by a $100 \mathrm{msec}$ prepulse to the starting potential. Between ramps, the membrane was held either at the cell resting potential (cell-attached) or at $-75 \mathrm{mV}$ (inside-out and outsideout). In a typical experiment, individual current responses elicited by 50 identical voltage ramps, applied every $500 \mathrm{msec}$, were recorded. The average behavior of the currents (i.e., the $I-V$ relationship) was assessed by computing the average of the 50 responses and is referred to as the ensemble current. Leakage currents were subtracted using a leakage template generated either by fitting a straight line to observed closed current segments within a single ramp trace or to closed segments selected from 20-50 different ramp currents elicited by the same voltage ramp. The current-voltage $(I-V)$ relation for open channels was obtained by averaging open current segments selected from an ensemble of currents elicited by the same ramp voltage and then subtracting the leakage from the averaged currents using leakage templates. In all cases, leak currents have been subtracted from displayed ramp current traces.

Channel density in cell-attached recordings. Pipette resistances of similar average resistance $(5-6 \mathrm{M} \Omega)$ have been used. The channel density of a cell-attached patch was estimated from ramp current responses at days 2 and 8 . For $K_{\mathrm{IR}}$ channels, the maximum number of major conductance levels observed among an ensemble of 50 individual ramp current responses was assumed to be equal to the number of channels per patch. For $\mathrm{K}_{\mathrm{O}}$ channels, in which stepwise channel activities were difficult to resolve during a vollage ramp (as in Fig. 2, right column), the maximum observed slope conductance (between +75 and +105 $\mathrm{mV}$ ) was divided by the average single-channel conductance from the same postnatal day. To obtain channel density, the area of the cellattached membrane patch under the pipette was calculated using the relation between pipette resistance and patch area given by Figure 8 of Sakmann and Neher (1983). For cell-attached recordings at days 2 and 8 , the average recording area was 2.7 and $2.33 \mu \mathrm{m}^{2}$ using the respective pipette resistances of $5.09+0.27 \mathrm{M} \Omega(n=41)$ and $6.28 \pm 0.26 \mathrm{~m} \Omega(n$ $=48$ ).

$\mathrm{p}_{0}$ for $K_{\mathrm{IR}}$ channels during a voltage ramp. The open channel probability for the $K_{I R}$ channels during a voltage ramp was obtained by dividing the average current by the open channel current measured at the same voltage, as described previously (Barres et al., 1988). Currents were filtered at $2 \mathrm{kH} \zeta$ and sampled every $300 \mu \mathrm{sec}$.

\section{Continuous recordings}

Single-channel currents (cell-attached) were filtered at a cutoff frequency of $1 \mathrm{kHz}(-3 \mathrm{~dB}$, Bessel) and sampled at 5 times this frequency (Colquhoun and Sigworth, 1983). Only patches with 1 channel were used in the analysis. Duration histograms were obtained from idealized records using the half-amplitude threshold analysis method (Colquhoun and Sigworth, 1983).

$\mathrm{p}_{\mathrm{o}}$ for $K_{\mathrm{IR}}$ channels during steady-state recordings. To estimate the open channel probability during steady-state recordings, a point-bypoint amplitude histogram was obtained from the actual current records by dividing the amplitude range of the signal into 512 bins $(0.024 \mathrm{pA} /$ bin) and counting the number of points per bin. A probability density histogram of the current amplitude was obtained by dividing the number of events per bin by the total number of events in the record and the bin width, as described previously (Sakmann and Trube, 1984b). In a patch with only 1 channel, this yields a probability histogram with 2 major peaks, corresponding to the open and closed current levels. For display, the absolute current level corresponding to the closed state was subtracted from the amplitude values so that the closed current histogram has a peak at zero current (Fig. $8 A$ ). $p_{\mathrm{n}}$ was calculated as the ratio of the area under the open peak to the total histogram area (Sakmann and Trube, 1984b). In cases where the 2 peaks overlapped (e.g., bottom of Fig. 8A), a Gaussian distribution (dashed line) was fit to the closed current distribution and $p_{0}$ was estimated by dividing the area outside the curve by the total area.

\section{Solutions}

Cells normally were bathed in Locke solution containing (mм): $\mathrm{NaCl}$, $154 ; \mathrm{KCl}, 5.6 ; \mathrm{CaCl}_{2}, 2.2$; morpholinopropionyl sulfonate buffer ( $\mathrm{pH}$ 7.4), 10. In excised outside-out recordings, the pipette was filled with a $140 \mathrm{~mm} \mathrm{KCl}$ solution, which contained (mM) KCl, $140 ; \mathrm{CaCl}_{2}, 1 ; \mathrm{MgCl}_{2}$, 2; EGTA, 10; HEPES buffer, 10; the pH of the solution was brought to 7.2 by addition of $27 \mathrm{~mm} \mathrm{NaOH}$. In cell-attached or inside-out recordings, pipettes were filled with a modified Locke solution containing 160 mM KCl $\left(\mathrm{Na}^{+}\right.$replaced with $\left.\mathrm{K}^{+}\right)$. Bath solutions used in inside-out patch experiments examining the effects of cytoplasmic $\mathrm{Mg}^{2+}$ contained (mM): $\mathrm{KCl}, 150$; HEPES, 5; $\mathrm{MgCl}_{2}$, 5; and $\mathrm{K}_{2} \mathrm{ATP}, 4$ (pH 7.3). The free $\mathrm{Mg}^{2+}$ in this solution was estimated to be $1.2 \mathrm{~mm}$ by using an apparent dissociation constant of $50 \mu \mathrm{M}$ (Vandenberg, 1987). The essentially $\mathrm{Mg}^{2+}$-free solution was the same except that $\mathrm{MgCl}_{2}$ was omitted. If a trace concentration of $15 \mu \mathrm{M} \mathrm{Mg}^{2+}$ was assumed (Vandenberg, 1987), the free ionized $\mathrm{Mg}^{2+}$ was estimated to be $0.2 \mu \mathrm{M}$.

\section{Electron microscopy}

Sciatic nerves were fixed with $4 \%$ glutaraldehyde in $0.1 \mathrm{~m}$ phosphate buffer ( $\mathrm{pH} 7.2$ ) for $1 \mathrm{hr}$ at $4^{\circ} \mathrm{C}$. Day 45 nerves were prefixed in situ for $15 \mathrm{~min}$ and then excised and placed back in fixative for an additional $5 \mathrm{hr}$. After fixation, nerves were rinsed in phosphate buffer, postfixed in $2 \%$ Dalton's chrome-osmium reagent, dehydrated, and embedded in Durcupan. The degree of myelination was quantified by counting the number of Schwann cells in one grid having at least one myelin lamella, and the number of myelin lamellae per cell. Myelinating cells were identified by their $1: 1$ association with axons. Myelin lamellae were identified as the major dense lines.

Whenever possible mean values \pm SEM are given. All patch-clamp experiments were done at a room temperature of around $25^{\circ} \mathrm{C}$.

\section{Results}

\section{Morphology of developing Schwann cells}

Figure 1 shows sciatic nerve fibers freshly isolated from rats at postnatal day $1(A), 2(B), 4(C)$, and $8(D)$ as viewed under Hoffman optics from the recording chamber during patch-clamp experiments. Already at day $1(A)$, cells beginning to myelinate axons $(\leftarrow)$ can be identified clearly; however, their occurrence is rare and exceptionally long stretches of exposed axon $(B, 4)$ still are observed. These long nodes could be normal for this age or a result of stretching during isolation while myelin still is loose. Bundles (*) containing fibers and rounded cell bodies also are common. These bundles presumably are the fetal bundles containing unsorted axons described by Friede and Samorajski (1968). Cells within these bundles are not examined in the present study. At later days, the number of myelin-forming Schwann cells rapidly increases. Myelin sheaths appear thicker and more luminous, and nodes of Ranvier become more normal $(D, 4)$. Some of these observations are presented in finer detail in the corresponding electron microscopic sections of Figure $1, E-H$.

\section{Two types of potassium channels in newborn Schwann cells}

All patch-clamp recordings in the present study are made at the soma of Schwann cells with visible myelin formation. Using pipettes filled with $160 \mathrm{mM} \mathrm{KCl}$ Locke solution and normal Locke solution in the bath, recordings from cell-attached patches during the first postnatal week reveal 2 predominant channel types. Representative current responses to a linear voltage ramp from -150 to $+150 \mathrm{mV}$ with respect to the resting potential are shown in Figure 2. The top 3 traces of each column are individual records, and the bottom trace is the ensemble average of 50 such records. 

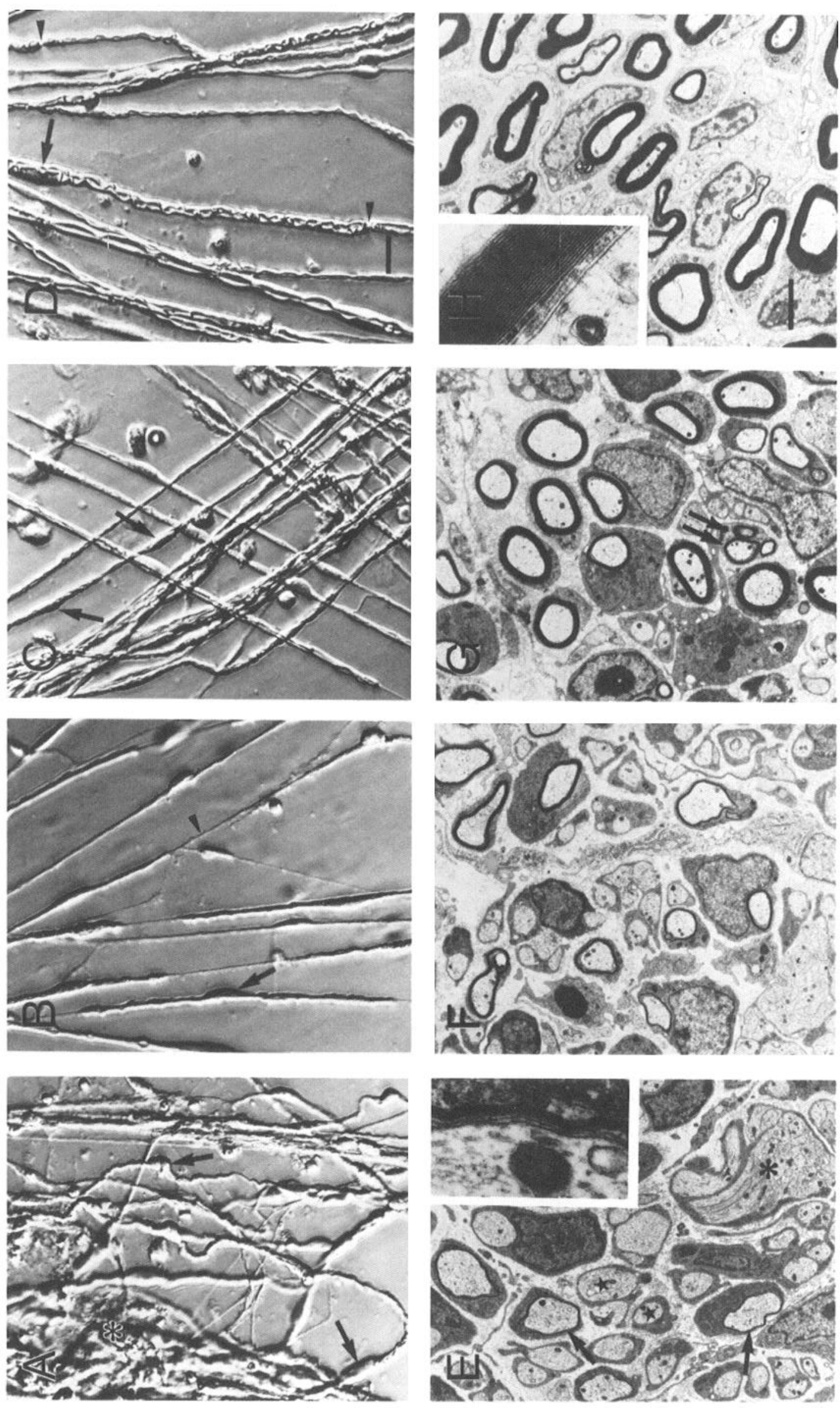

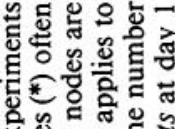

ชe.

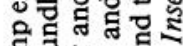

हैं है

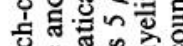

政

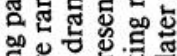

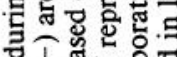

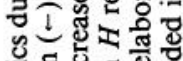

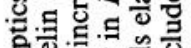

웡

年

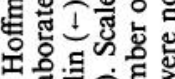

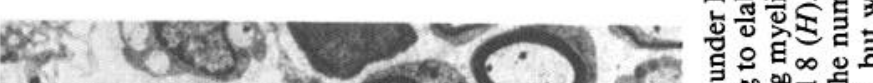

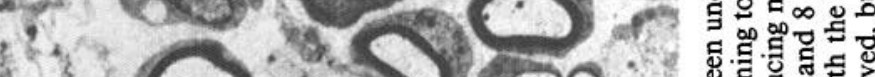

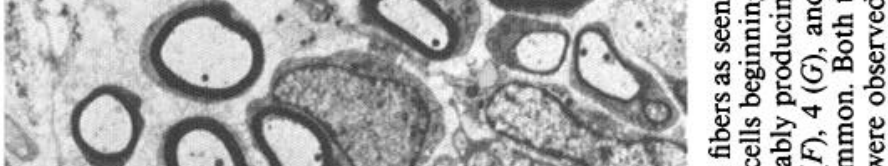

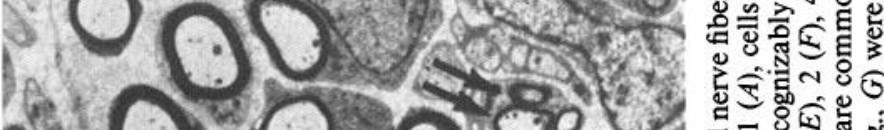

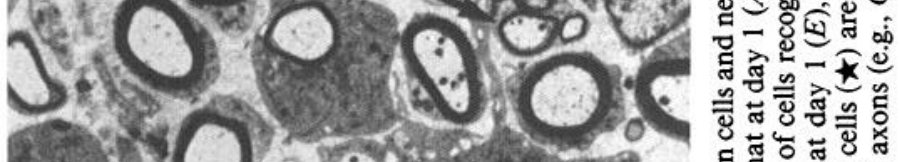

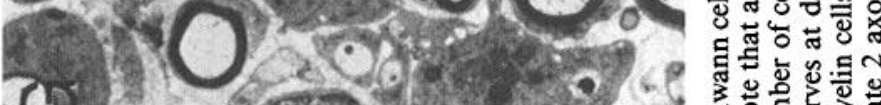

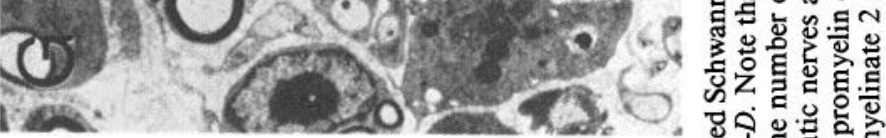
(1) I

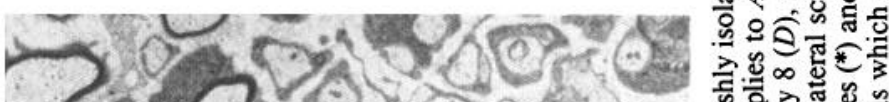

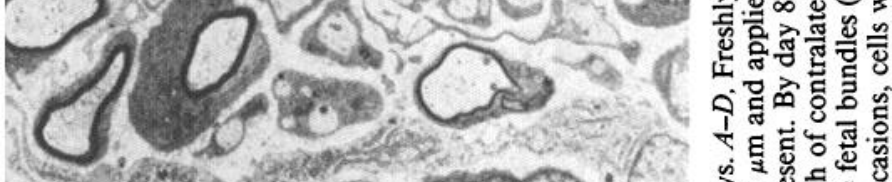

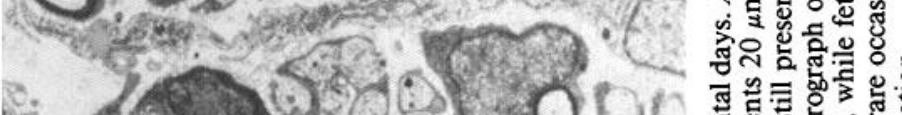

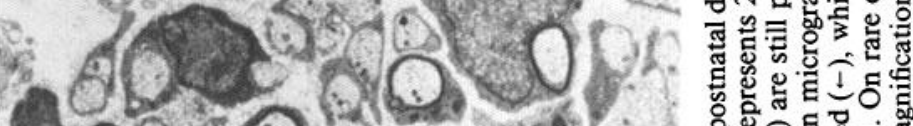

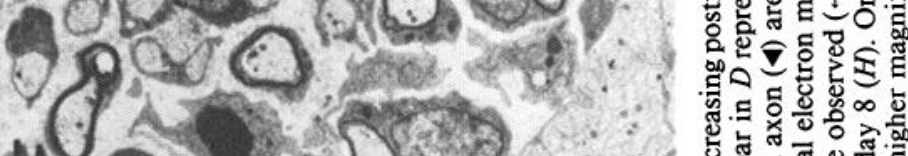

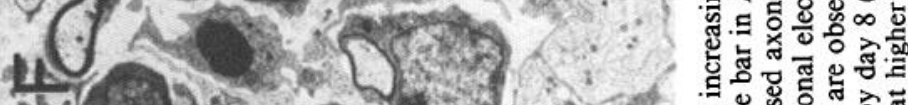

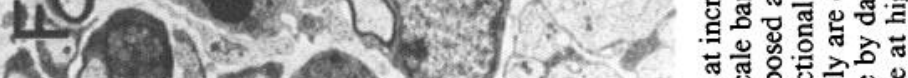

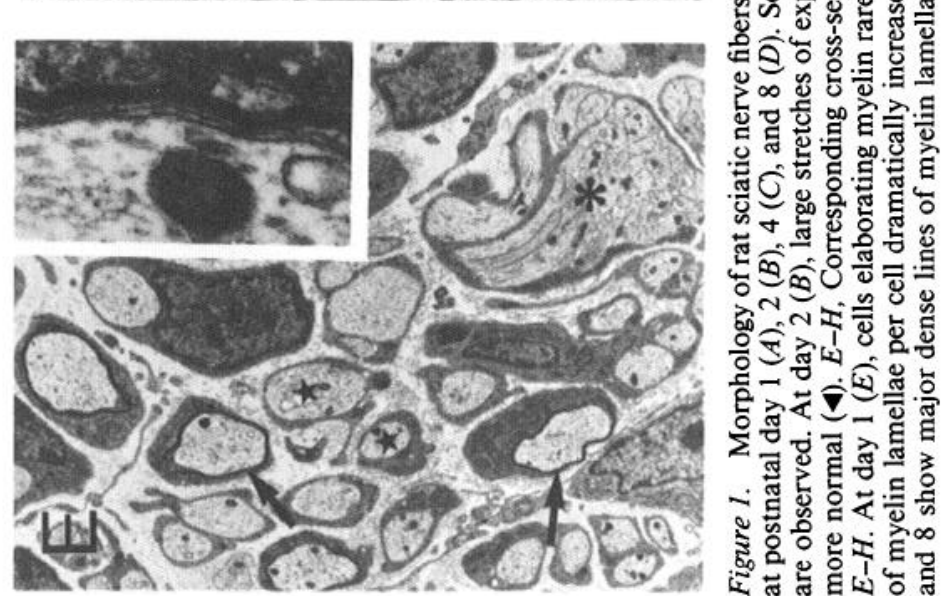

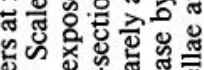


$\mathrm{K}_{\text {IR }}$

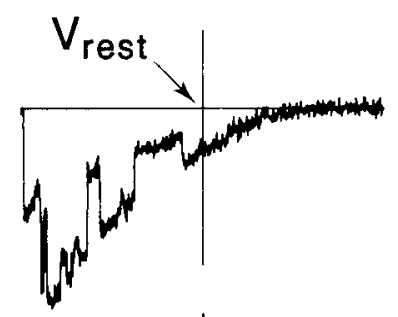

Figure 2. Potassium channels in cellattached patches from soma of newborn Schwann cells. Representative current traces from patches containing $\mathrm{K}_{\mathrm{IR}}$ channels during a voltage ramp (left column; day 3 ), $\mathbf{K}_{0}$ channels (middle column, day 3), or both channel types (right column, day 2). Inward current is plotted downwards. Each column shows 3 individual traces followed by the ensemble average of 50 such traces. Currents were elicited by a voltage ramp from -150 to $+150 \mathrm{mV}(0.83 \mathrm{~V} / \mathrm{sec})$ relative to the resting potential. Ramps were preceded by a $100 \mathrm{msec}$ prepulse to the starting ramp potential $(-150$ $\mathrm{mV}$ ) and $500 \mathrm{msec}$ elapsed between the end of each ramp and the start of the next prepulse. Data were filtered at 2 $\mathrm{kHz}$ and sampled every $300 \mu \mathrm{sec}$. Leak currents were subtracted using a leak template as described in Materials and Methods. Pipette contained a $160 \mathrm{~mm}$ $\mathrm{KCl}$ Locke solution; bath, normal Locke solution.
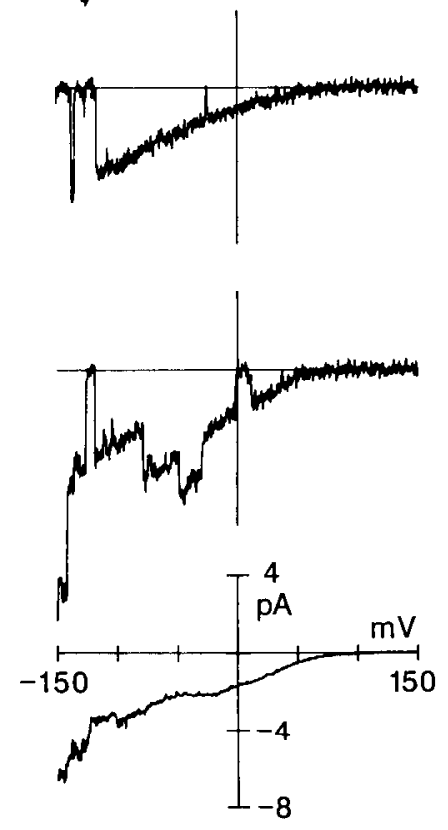
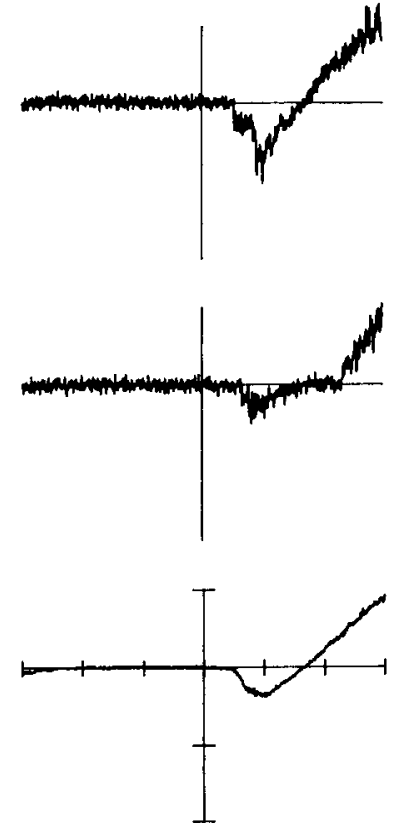
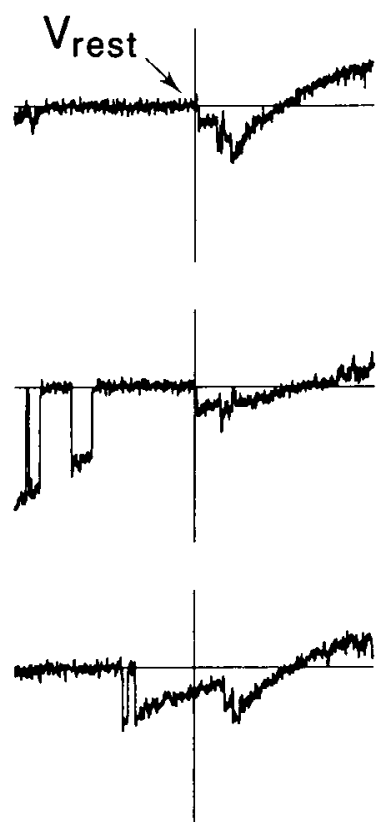

Both

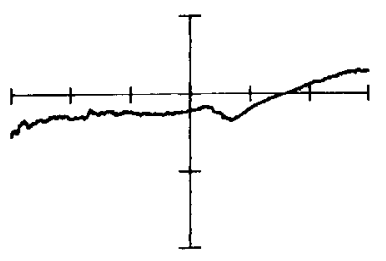

$K_{I R}$ channel. The left column in Figure 2 shows responses from a cell-attached patch containing only 1 channel type. Single-channel activity is observed in response to hyperpolarizing voltages, and this channel preferentially carries inward current. Both individual records and the ensemble current clearly show that the channel is active at physiologically effective potentials around rest. Multiple conductance levels (presumably reflecting multiple channels) are frequently observed. Figure $3 A$ shows an open channel $I-V$ relationship from a patch with only $l$ channel. The slope conductance of $35 \mathrm{pS}$, as determined between -150 and $-90 \mathrm{mV}$ relative to rest, is typical for Schwann cell $\mathrm{K}_{\mathrm{IR}}$ channels.

$K_{o}$ channel. Another channel type often encountered is shown in the middle column of Figure 2. In contrast to the $\mathrm{K}_{\mathrm{IR}}$ channel, this channel activates only at potentials approximately $25 \mathrm{mV}$ positive to the resting potential and carries both inward and outward current. In instances where discrete channel openings can be discerned, the slope conductance of a single channel is estimated to be about $13 \mathrm{pS}$, in agreement with the conductance noted by Shrager et al. (1985) for Schwann cell delayed rectifiers. No detailed kinetic analysis of this channel is pursued.

The kinetic difference between the 2 channels clearly allows them to be distinguished, even in patches with both channels present (Fig. 2, right column).

$K^{+}$substitution and pharmacological block. The major ion carried by both channels appears to be potassium. Figure $4 \mathrm{~A}$ shows the effect of switching the external $\mathrm{K}^{+}$concentration from 5.6 to $160 \mathrm{~mm}$ in an outside-out patch with both channels present. $\mathrm{K}^{+}$substitution results in a shift of the apparent reversal potential of the ensemble current to around $0 \mathrm{mV}$ and, at least for the $\mathrm{K}_{\mathrm{IR}}$ component, a dramatic increase in current magnitude is observed. Examination of individual records (not shown) reveals that the increase in $\mathrm{K}_{\mathrm{IR}}$ current size is due primarily to an increase in single-channel conductance $(\gamma)$. Indeed, $\gamma\left(\mathrm{K}_{\mathrm{IR}}\right)$ appears proportional to the square root of the extracellular $\mathrm{K}^{+}$ concentration (Fig. $3 B$ ) as noted for other inward rectifiers (Sakmann and Trube, 1984a; Barres et al., 1988).

The 2 potassium channels also are distinguished by their differential sensitivity to known potassium channel blockers. When the patch is superfused with $5 \mathrm{mM} \mathrm{Cs}^{+}$in $160 \mathrm{~mm} \mathrm{KCl} \mathrm{Locke}$ solution, the current component corresponding to the $\mathrm{K}_{\mathrm{IR}}$ channel is blocked almost completely (Fig. $4 B$ ). In contrast, the inward current component of the $\mathrm{K}_{\mathrm{O}}$ channel is left intact. Replacing $\mathrm{K}^{+}$with $\mathrm{Cs}^{+}$, as in Figure $4 C$, effectively removes all sign of inward current from the responses of both channels. In addition, when compared to the $\mathrm{K}_{\mathrm{O}}$ channel, the $\mathrm{K}_{\mathrm{IK}}$ current also appears more sensitive to block by $4 \mathrm{AP}$. In another outsideout patch with both channels present (Fig. 4D), $10 \mathrm{~mm} \mathrm{4AP}$ primarily blocked the $\mathrm{K}_{\mathrm{IR}}$ current. Similar results were obtained in 5 other cells. 

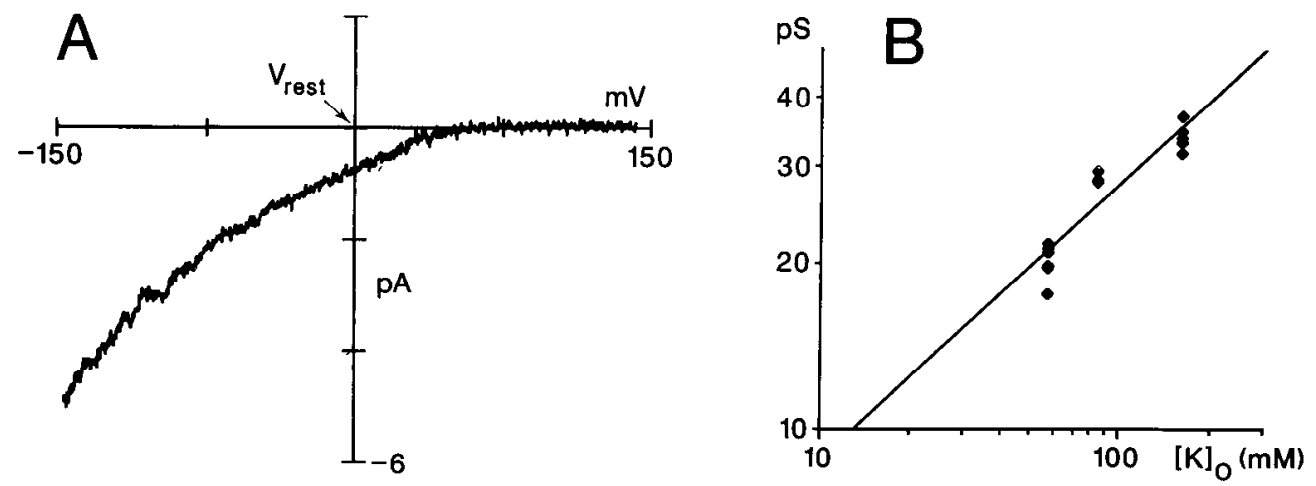

Figure 3. $\mathrm{K}_{\mathrm{IR}}$ single-channel conductance. $\gamma$ is measured between -150 and $-90 \mathrm{mV}$ relative to the resting potential in cell-attached patches. $A$, Typical open channel $I-V$ relationship determined by averaging leak-subtracted open segments selected from a series of individual current traces elicited by the same ramp protocol (see Materials and Methods). Pipette contained $160 \mathrm{~mm} \mathrm{KCl}$ Locke solution; bath, normal Locke solution. Under these conditions, $\gamma$ for this cell is $35 \mathrm{pS}$. Note the marked inward rectification as the ramp potential approaches and exceeds $E_{\mathrm{K}}$. $B$, $\gamma$ dependence on $\left[\mathrm{K}^{+}\right]_{0}$. Data from 15 cell-attached patches with $\mathrm{K}^{+}$concentration in the pipettes as indicated; bath contained normal Locke solution. Data plotted on double-logarithmic coordinates. The straight line represents the best fit to the data according to the equation $\gamma=2.75 \times\left[\mathrm{K}^{+}\right]_{0}^{0.503}$.

\section{The $K$ currents are down-regulated with progressive myelination}

To quantify changes in somal currents, 30-50 ensemble currents from different patches have been averaged for each day $(1,2$, 3 , and 8) and are shown in Figure 5 (inset). The corresponding postnatal change in the average number of myelin lamellae per Schwann cell is measured from EM sections (Fig. 1) of contralateral sciatic nerves from the same animal used for patch-clamp recordings. The result is shown in Figure 5, where the postnatal changes in myelin lamellae per cell are compared with the corresponding change in the average $K_{I R}$ and $K_{O}$ amplitudes, measured at -130 and $+140 \mathrm{mV}$ relative to the resting potential, respectively. While $\mathrm{K}_{\mathrm{IR}}$ currents virtually disappear from the cell soma by day 8 , somal expression of $K_{O}$ currents appears more protracted and down-regulation is not complete until sometime during the first postnatal month. More importantly, the increase and subsequent marked decrease of both currents clearly occurs during the initial and most rapid (Friede and Samurajski, 1968) phase of myelin formation.

Factors responsible for the reduction in ensemble currents. As can be seen in Figure 5, the average ensemble currents undergo a $82 \%\left(\mathrm{~K}_{\mathrm{O}}\right)$ and $94 \%\left(\mathrm{~K}_{\mathrm{IR}}\right)$ decline from day 2 to day 8 . According to the equation $I=N \gamma p_{\curvearrowright}\left(E-E_{\mathrm{K}}\right)$, these current reductions could be due to a reduction in the number of channels per cellattached patch $(N)$, the single channel conductance $(\gamma)$, the open channel probability $\left(p_{\mathrm{o}}\right)$, or the driving force $\left(E-E_{\mathrm{K}}\right)$. The following arguments show that a reduction in $N$ accounts for most of the current reduction, at least for the $\mathrm{K}_{\mathrm{IR}}$ currents.

First, $\gamma\left(\mathrm{K}_{\mathrm{IR}}\right)$, measured as the slope conductance between -150 and $-90 \mathrm{mV}$ relative to the resting potential, is virtually identical between day $2[34.3 \pm 0.9 \mathrm{pS}(n=5)]$ and day 8 [34.9 $\pm 1.5 \mathrm{pS}(n=3)]$. The corresponding $\gamma\left(\mathrm{K}_{\mathrm{o}}\right)$ at these 2 days, measured between +75 and $+105 \mathrm{mV}$ relative to the resting potential, also does not appear to change [13.9 $\pm 0.6 \mathrm{pS}(n=$ 4) and $13.4 \pm 0.47 \mathrm{pS}(n=10)$ at days 2 and 8 , respectively].
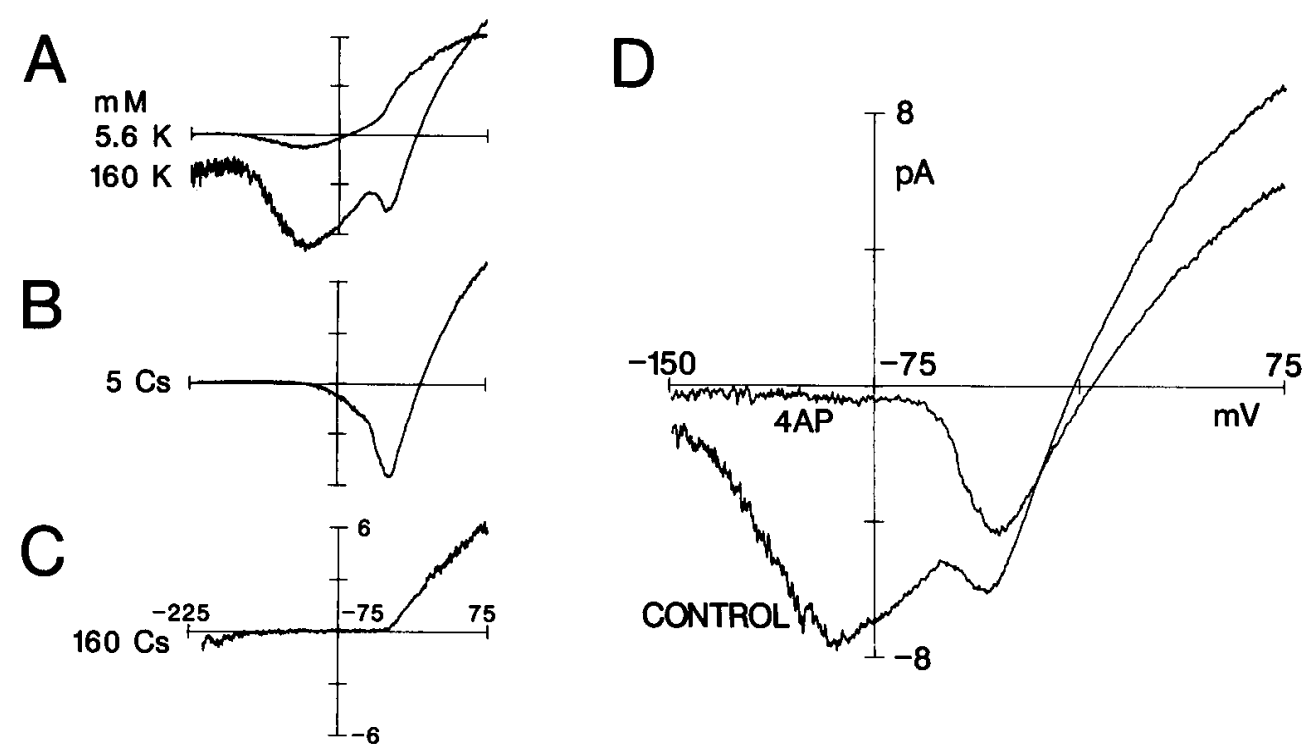

Figure 4. Effects of extracellular $\mathrm{K}^{+}$, $\mathrm{Cs}^{+}$, and $4 \mathrm{AP}$ on ensemble ramp currents in outside-out patches. $A$, Superimposed responses when the external solution was switched from a normal Locke solution $(5.6 \mathrm{~mm} \mathrm{KCl})$ to a modified one containing $160 \mathrm{~mm} \mathrm{KCl} . B$, External solution switched to one containing $5 \mathrm{~mm} \mathrm{CsCl}$ in addition to 160 mм KCl. $C$, External solution switched to one in which $\mathrm{KCl}$ was replaced by $160 \mathrm{~mm} \mathrm{CsCl}$. $D$, Effect of $4 \mathrm{AP}$ on $\mathrm{K}_{\mathrm{IR}}$ and $\mathrm{K}_{\mathrm{O}}$ currents in a separatc patch. Superimposed ensemble ramp currents (day 3) before and during superfusion with a $160 \mathrm{~mm} \mathrm{KCl} \mathrm{Locke} \mathrm{solution} \mathrm{con-}$ taining $10 \mathrm{~mm}$ 4AP. In all cases, test solutions were delivered by gravitation flow through a pipette $(\sim 3 \mu \mathrm{m}$ tip diameter). Patches were placed within the mouth of the pipette, and currents were measured 3-5 min after switching to the indicated solution. Pipette solution contained 140 mм KCl. Data were filtered at $2 \mathrm{kHz}$ and sampled every 300 $\mu \mathrm{sec}$ 
Figure 5. Comparison of the early postnatal change in the number of myelin lamellae with the somal $\mathrm{K}_{\mathrm{IR}}$ and $\mathrm{K}_{\mathrm{O}}$ currents. Average current amplitudes were measured from the ramp $I-V$ relationship (inset) at $-130\left(\mathrm{~K}_{\mathrm{IR}}\right)$ and $+140 \mathrm{mV}\left(\mathrm{K}_{\mathrm{O}}\right)$. The number of myelin lamellae was determined in electron microscopy by counting the number of major dense lines in cells associated with only one axon. Cells in 1:1 association with axons but not yet elaborating myelin (promyelin cells) were not included in the average. The number of cells observed in a fixed area with one or more major dense lines was 40 (day 1), 115 (day 2), 155 (day 3), 183 (day 4), 204 (day 8), and 87 (day 45). Inset, Each trace represents the average of all ensemble ramp currents obtained from different cell-attached recordings at each indicated day. The number of cells examined are 35, 41, 29, and 48 at days $1,2,3$, and 8 , respectively. Pipettes contained $160 \mathrm{~mm} \mathrm{KCl} \mathrm{Locke} \mathrm{solution;}$ bath, normal Locke solution. Electrophysiological and morphological data were obtained from 2 different litters of newborn rats; each day, 2 rats, one from were obtained from nerves contralateral to those used in electrophysiology. each litter, were used. Myelin counts
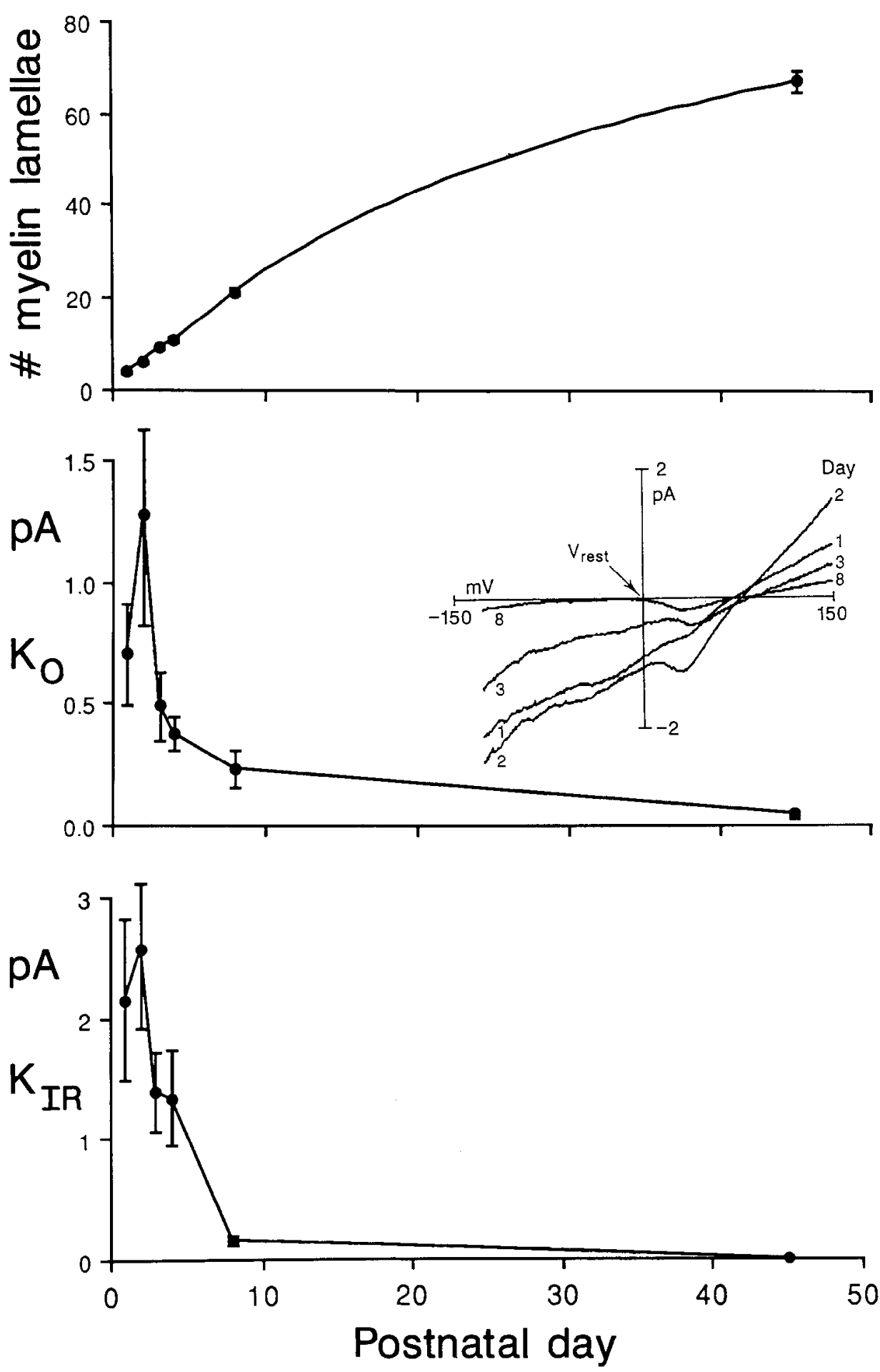

Second, at least for the $\mathrm{K}_{\mathrm{IR}}$ channels, $p_{\mathrm{o}}$ can be computed from ramp currents (see Materials and Methods). Based mostly on patches with only 1 channel, $p_{\mathrm{o}}$ at $-130 \mathrm{mV}$ (relative to rest) is $0.32 \pm 0.025(n=5)$ at day 2 and is reduced to $0.15 \pm 0.04$ $(n=3)$ at day 8 . However, since only 3 out of 48 patches at day 8 contained observable $\mathrm{K}_{\mathrm{IR}}$ channels, calculations show that even if $p_{\mathrm{o}}$ remained unchanged from days $2-8$, the average ensemble current still would decline by $90 \%$. The possibility that channels are present but not detectable cannot be excluded. However, reversing the direction of the voltage ramp did not reveal channel activities in patches which may have been silent due to channel inactivation. Third, the driving force for potassium currents can be estimated from Figure 5 (inset) as the difference between a given potential and the reversal potential of the ensemble currents. This yields a variation in driving force of at most $\sim 7$ and $\sim 18 \%$ at $-130 \mathrm{mV}\left(\mathrm{K}_{\mathrm{IR}}\right)$ and $+140 \mathrm{mV}$ $\left(\mathrm{K}_{\mathrm{o}}\right)$ between recordings from different postnatal days. Indeed, closer examination of the inset shows that for $K_{o}$ currents, the driving force at day 2 is actually slightly smaller than that at day 8 , a change opposite to that needed to explain the current reduction.

Further support for the notion that a decline in $N$ largely 
A
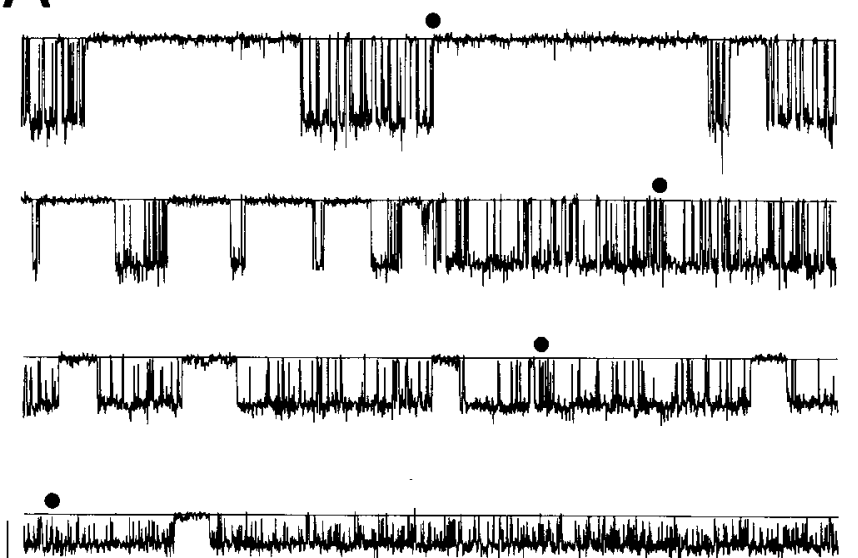

$2 \mathrm{pA}$
B
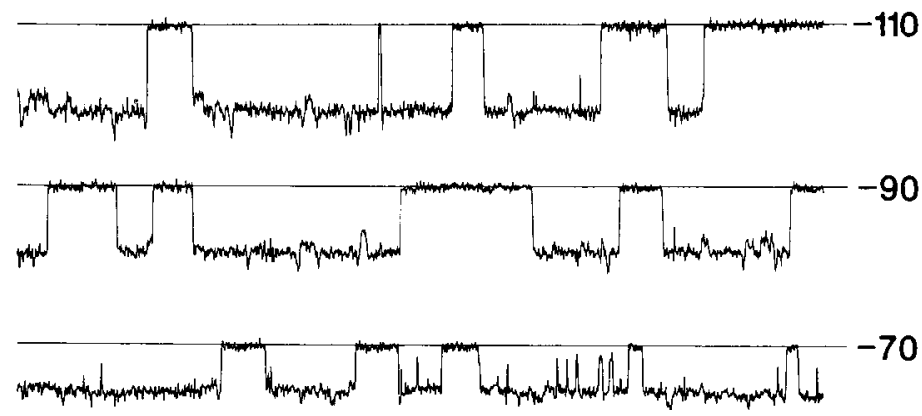

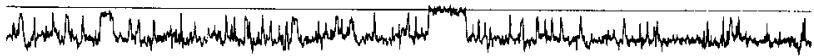
$-50$

$50 \mathrm{~ms}$

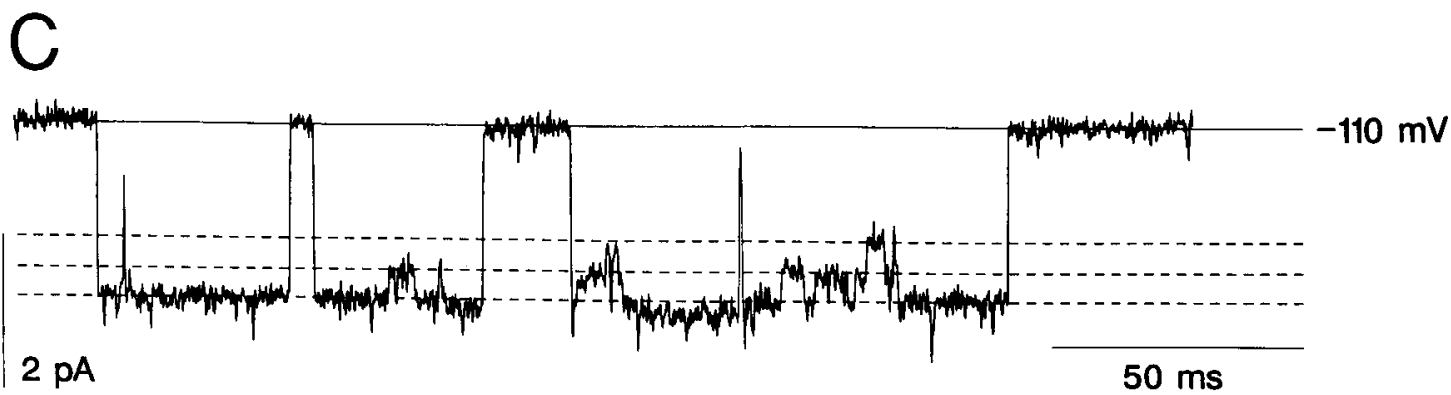

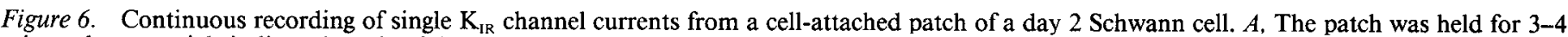

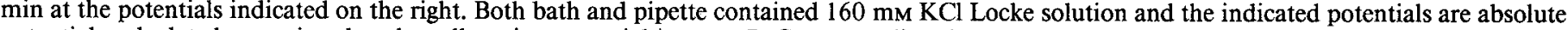

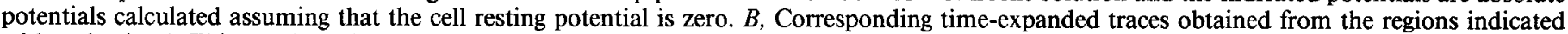

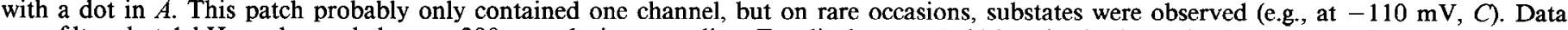

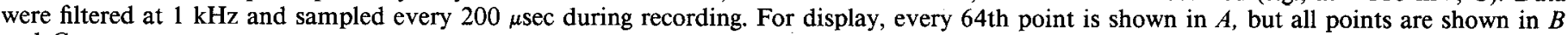
and $C$.

accounts for the decline in the $\mathrm{K}_{\mathrm{IR}}$ ensemble currents comes from a direct estimate of the number of channels per patch. Thus, $N$ is $1.17 \perp 0.3(n=41)$ at day 2 and $0.083 \pm 0.05(n$ $=48$ ) at day 8 , which corresponds to a respective channel density of 0.43 and 0.036 channels $/ \mu \mathrm{m}^{2}$ after converting the similar pipette resistances at these 2 days to membrane patch area (see Materials and Methods). This $92 \%$ reduction in channel density is in agreement with the corresponding $94 \%$ decline in $\mathrm{K}_{\mathrm{IR}}$ ensemble currents. For $\mathrm{K}_{\mathrm{O}}$ channels, the estimated channel density declined by about $62 \%$ from day 2 to 8 ( 0.6 to 0.23 channels/ $\left.\mu \mathrm{m}^{2}\right)$ as compared with the $82 \%$ decline in average ensemble currents.

\section{Kinetic properties of $K_{I R}$ channels in steady-state recording}

Figure $6 \mathrm{~A}$ shows half-minute segments of continuous recordings from a cell-attached patch at holding potentials of $-110,-90$, -70 , and $-50 \mathrm{mV}$ with $160 \mathrm{~mm} \mathrm{KCl}$ Locke in both pipette and bath. The absolute potentials in this figure are calculated assuming that, under these conditions, the cell resting potential is zero. As can be seen for the record at $-110 \mathrm{mV}$, one feature of the $\mathrm{K}_{\mathrm{IR}}$ channel is bursting. There appears to be an increase in burst duration and a decrease in interburst interval as the patch is depolarizing from -110 to $-50 \mathrm{mV}$. This apparently leads to a more frequent occupancy of the open state. Closer examination of the corresponding time-expanded traces in Figure $6 B$ shows, in addition, that both open and closed times within a burst actually shorten as the patch is depolarized.

The duration histograms for the above cell are presented in Figure 7. As expected, the distribution of closed durations $(A)$ at most potentials requires a sum of 2 exponentials $\left(\tau_{\text {fast }}\right.$ and $\tau_{\text {slow }}$ ) for good fit, indicating a minimum of 2 closed states for this channel. In addition, since closed durations longer than 150 msec are omitted in this analysis, at least 1 additional closed state is probable. In contrast to the closed time distributions, open time distributions (Fig. $7 B$ ) are well fit by a single exponential $\left(\tau_{\mathrm{o}}\right)$. In addition, $\tau_{\mathrm{o}}$ clearly is more voltage-dependent, decreasing approximatcly 10 -fold over the same potential range. Finally, on rare occasions, close inspection of the records reveals presumed substates of approximately equal amplitudes (Fig. 6C).

The steady-state $p_{\mathrm{o}}$ of the channel was estimated from the probability density histograms of the current amplitudes shown in Figure $8 A$. $p_{0}$ increases from 0.38 to 0.87 as the membrane is depolarized from -110 to $-70 \mathrm{mV}$. However, upon further depolarization to $-30 \mathrm{mV}, p_{\mathrm{o}}$ decreases to 0.49 . We cannot rule out the possibility that this reduction in $p_{0}$ is due to the increased difficulty in resolving channel openings at more depolarized potentials. However, the probability is calculated using a pointby-point histogram of the original data (see Materials and Methods) rather than idealized records, which eliminates the uncer- 

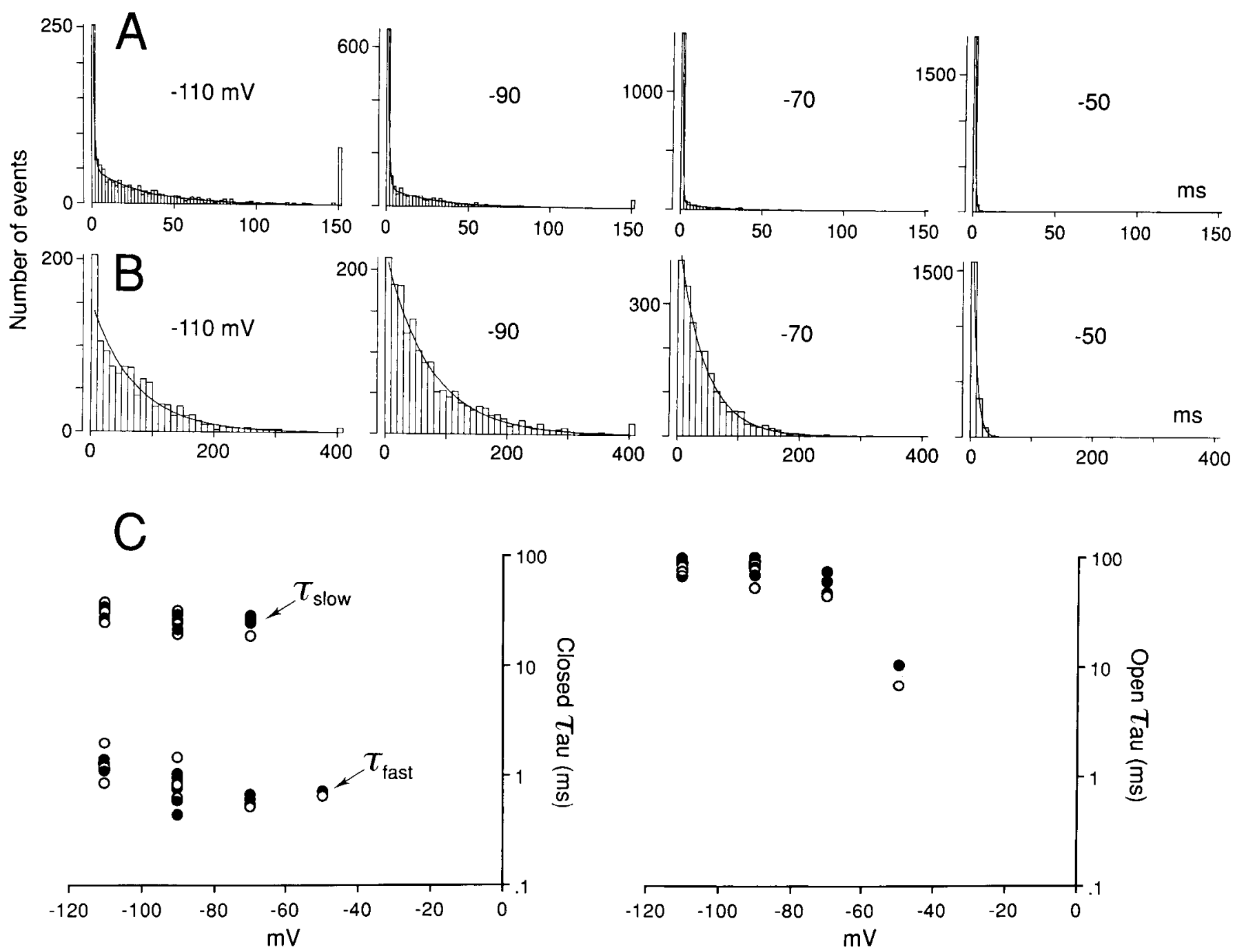

Figure 7. Duration analysis of $\mathrm{K}_{\mathrm{IR}}$ channels. Closed $(A)$ and open $(B)$ duration histograms at the indicated membrane potentials. Same patch as in Figure 6 . The closed time distributions were fit by a double-exponential curve $\left(\tau_{\text {fast }}, \tau_{\text {slow }}\right)$ except at $-50 \mathrm{mV}$, where $\tau_{\text {slow }}$ became unresolvable. The last bin in each histogram gives the number of closed durations exceeding $150 \mathrm{msec}(83,33,8$, and 2 for $-110,-90,-70$, and $-50 \mathrm{mV}$, respectively). Open times were fit by a single-exponential curve $\left(\tau_{\circ}\right)$, and the last bin gives the number of open durations exceeding $400 \mathrm{msec}(5$, 14,0 , and 0 for $-110,-90,-70$, and $-50 \mathrm{mV}$, respectively). $C$. Voltage-dependence of $\tau_{\text {fast }}$ and $\tau_{\text {slow }}$ for cell-attached patches at postnatal day 2 $(n=3,0)$ and day $5(n=5,9)$. Only patches with one active channel were used for analysis.

tainties due to assigning open and close times during the reconstruction procedures. Figure $8 B$ shows a plot of $p_{\text {o }}$ versus the membrane potential for day $2(n=3,0)$ and day $5(n=8$, ๑). The voltage-dependence is clearly bell-shaped with a peak at about $-60 \mathrm{mV}$.

Finally, when comparing day 2 and day 5 (based on patches with only 1 channel), there is no apparent difference in either channel kinetics (Fig. 7C), open channel probability (Fig. $8 B$ ), or their voltage-dependence.

\section{Mechanism of inward rectification- $\mathrm{Mg}^{2+}$}

In inward rectifiers of heart ventricular cells (Matsuda ct al., 1987; Vandenberg, 1987; Matsuda, 1988), $\left[\mathrm{Mg}^{2+}\right]_{i}$ appears to plug the channel and block outward current flow. The Schwann cell $\mathrm{K}_{\mathrm{IR}}$ channel appears to behave similarly in this regard. Figure 9 (left column) shows typical current rectification in a cellattached patch with $\mathrm{K}_{\mathrm{IR}}$ channels in a voltage ramp experiment. When the patch is excised and the cytoplasmic side is superfused with essentially $\mathrm{Mg}^{2+}$-free solution, an outward current appears and rectification is removed (middle column). Reintroduction of $\mathrm{Mg}^{2+}$ results in almost complete restoration of rectification (right column). $\mathrm{Mg}^{2+}$ appeared to exert similar effects in 8 other cells examined, although in most cells, the open channel probability appeared lower for potentials positive to $E_{\mathrm{K}}$ even in $\mathrm{Mg}^{2+}$-free solutions.

\section{Discussion}

Glial channels in axoglial interactions during development In developing mammalian peripheral nerves, Schwann cells originate from the neural crest and migrate along extending nerve fibers until they reach their approximate destination. Here, cells separate from fetal bundles, proliferate, decide their phenotype, and finally, ensheath axons (Webster and Favilla, 1984). During this sequence, it is highly probable that interactions of glia and axons are critical to the establishment of normally functioning nerves. The present study demonstrates that, un- 

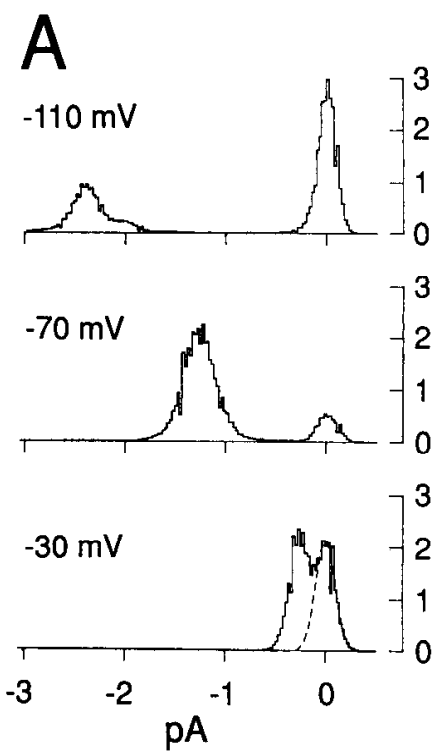

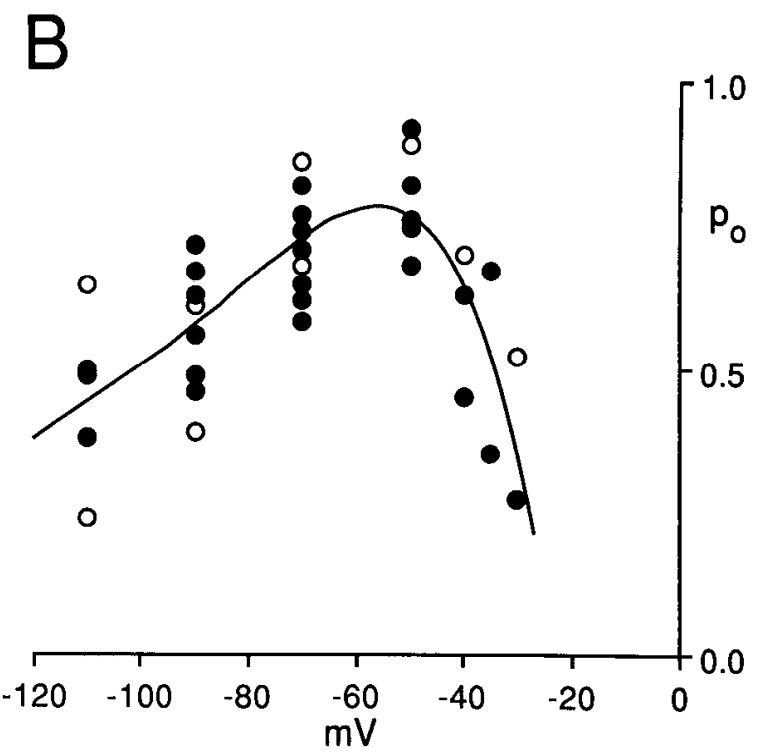

Figure 8. Voltage dependence of steady-state $p_{\mathrm{o}}$ for $\mathrm{K}_{\mathrm{IR}}$ channels. $A$, Probability density histograms of the current amplitudes for the cell-attached patch shown in Figure 6. Patch membrane potentials are indicated at left. The rightmost peak in each histogram corresponds to the closed state (see $\mathrm{Ma}$ terials and Methods). $B$, Voltage dependence of $p_{0}$ for patches at postnatal day $2(n=3,0)$ and day $5(n=8,0)$. The solid curve is a polynomial fit to the data. $p_{\mathrm{a}}$ is calculated as the ratio of the area under the open state peak to the total area of the histogram. When open and closed distributions merge (as in $A$ at $-30 \mathrm{mV}$ ), a Gaussian curve (dashed line) is fit to the closed peak and $p_{\mathrm{o}}$ is estimated by dividing the area outside the curve by the total area. The $p_{\mathrm{o}}$ were based on $1-4$ min segments of continuous recording at a given potential. Only patches with one active channel were used for analysis. doubtedly, glial channel expression either contributes to or reflects this delicate balance of events. Specifically, there are 2 potassium channel types (Fig. 2) detectable at Schwann cell soma during development, and these channels are down-regulated during the early phase of myelin formation (Fig. 5).

In the adult rabbit, whole-cell recordings at the soma of myelinating Schwann cells show that these cells lack detectable volt- age-dependent ionic currents (Chiu, 1987). The present study indicates that this characteristic of myelinating cells may not be decided as early as their phenotype. At postnatal day 1, Schwann cells expressing myelin also express channels. Although the most abrupt changes in channel density accompany the initiation of myelination, down-regulation of channels is not complete until at least one month after birth (Fig. 5).
A
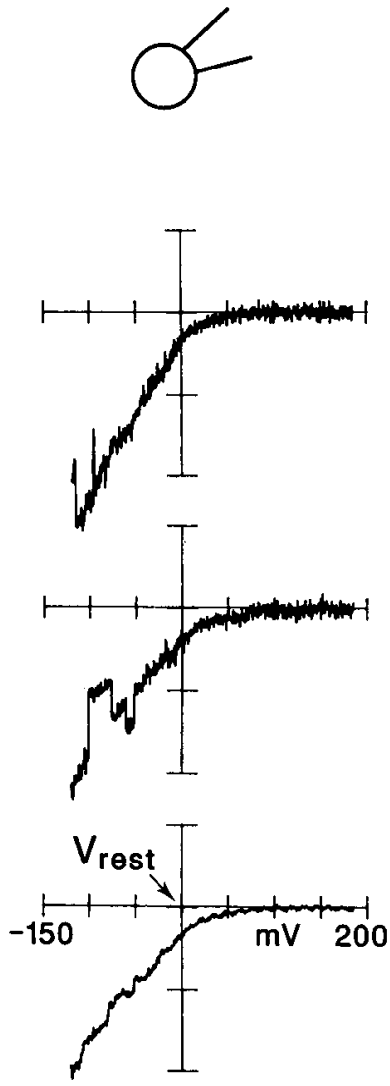

B
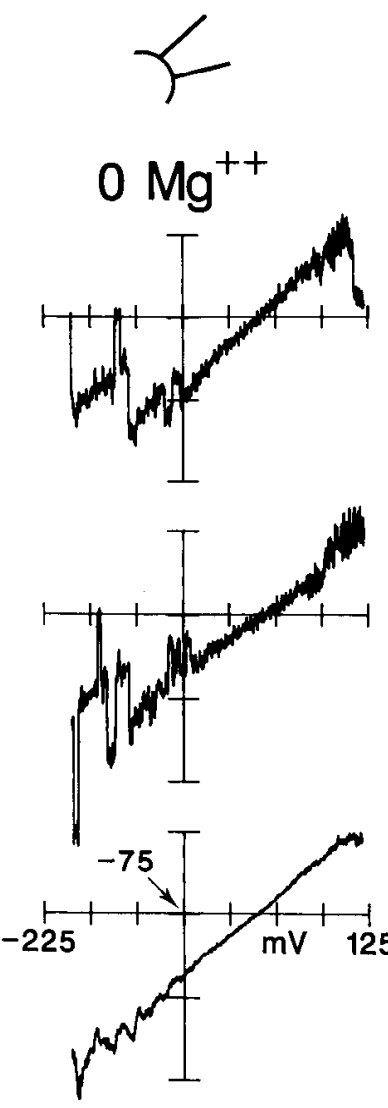
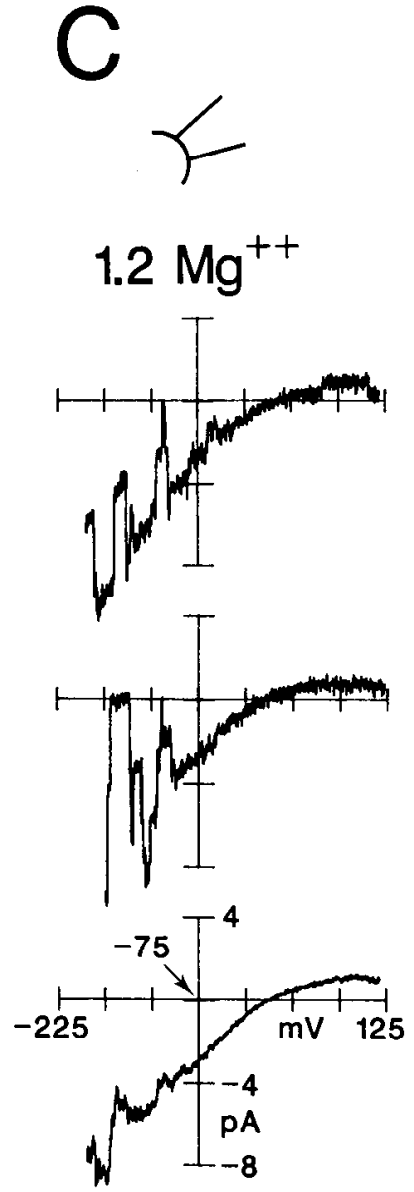

Figure 9. Effects of $\mathrm{Mg}^{2+}$ on rectification of $\mathrm{K}_{\mathrm{IR}}$ currents. Single and ensemble (bottom-most) ramp currents from the same cell, first in cell-attached configuration with normal Locke solution in the bath $(A)$, then excised to an inside-out configuration $(B, C)$. Before excision of the patch, the cell was superfused with a solution containing (mM): $150 \mathrm{KCl}, 5 \mathrm{HEPES}, 5 \mathrm{MgCl}_{2}$, and $4 \mathrm{~K}_{2}$ ATP $\left(\mathrm{pH}\right.$ 7.3). The free $\mathrm{Mg}^{2+}$ in this solution was estimated to be 1.2 mM (see Materials and Methods). Following excision and after moving the patch to the mouth of the perfusion pipette, the solution was switched to one in which no $\mathrm{Mg}^{2+}$ had been added $(B)$. The records shown were taken 2 min after solution change. Finally, the solution was returned to the one containing $1.2 \mathrm{~mm}$ free $\mathrm{Mg}^{2+}(C)$. Data were filtered at $2 \mathrm{kHz}$ and sampled every 300 $\mu \mathrm{sec}$. The pipette contained $160 \mathrm{mM} \mathrm{KCl}$ Locke solution. 


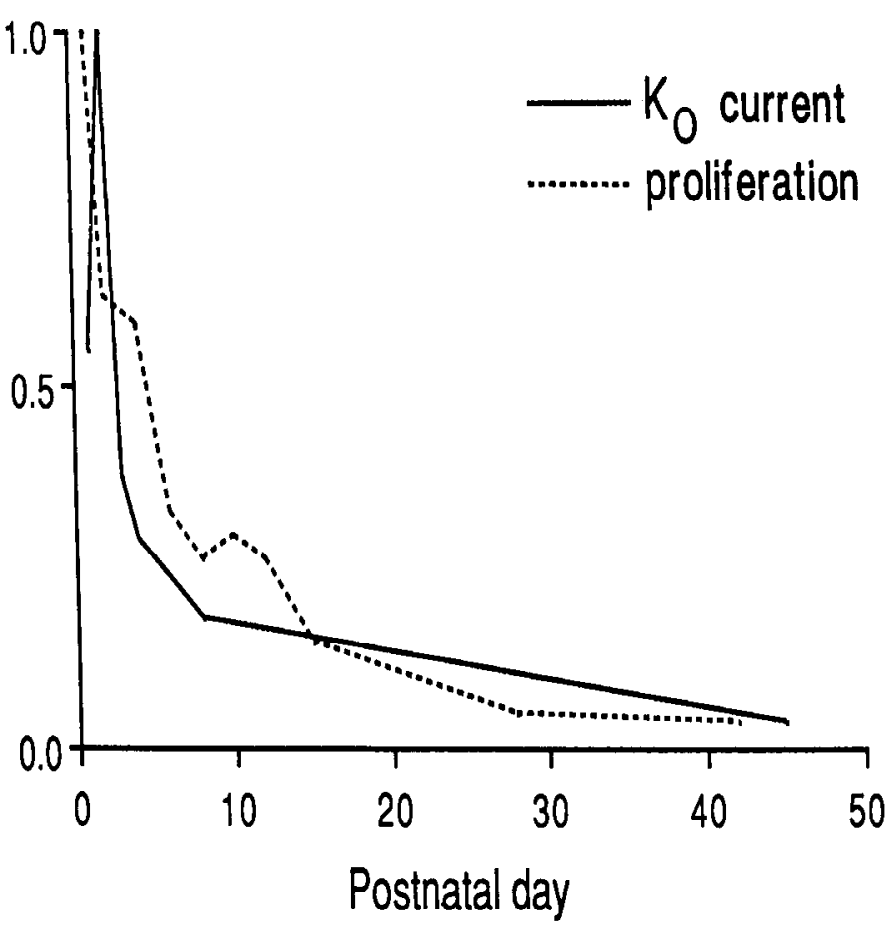

Figure 10. Comparison of postnatal changes in somal $\mathrm{K}_{\mathrm{O}}$ current (-) and proliferation (---) of rat Schwann cells. $K_{o}$ data taken from Figure 5 in this study. Proliferation data taken from table 2 of Friede and Samorajski (1986). The reported percentage of Schwann cells labeled with ${ }^{3} \mathrm{H}$-thymidine have been normalized so that the maximum incorporation $(27 \%$ at day 1$)$ is equal to unity in this figure.

\section{Nature of signal triggering channel expression}

Given that Schwann cells have been shown to influence the distribution of ion channels on axons (Waxman and Ritchie, 1985), an interesting question which follows is whether axon association similarly affects the distribution of Schwann cell ion channels. Contact with axons might trigger channel expression during early development. Current evidence suggests that in early development, axons determine Schwann cell phenotype (Aguayo et al., 1976) and axon association is required for proliferation of neonatal Schwann cclls (Wood and Bungc, 1975; Salzer and Bunge, 1980). Since up-regulation of outward potassium currents appears to be an intermediate step in the cascade of events leading to proliferation, it seems likely that contact with axons also triggers channel expression.

Is the signal triggering expression of inward and outward rectifying potassium channels the same? Preliminary results suggest a subtle difference. In vitro, multiple mitogens appear effective in stimulating Schwann cell outward currents and outward currents can appear in culture without axonal contact (Wilson and Chiu, 1988). In contrast, inward rectifying currents have not been observed in culture conditions.

\section{$\mathrm{K}_{\mathrm{IR}}$ channels: comparison to other inward rectifiers}

This is the first report of an inward rectifying potassium channel in normal Schwann cells. On the whole, Schwann cell inward rectifiers are quite similar to those observed in other mammalian tissues, for example, oligodendrocytes (Barres et al., 1988; Solvien et al., 1988) and heart ventricular myocytes (Sakmann and Trube, 1984a, b; Matsuda et al., 1987; Vandenberg, 1987; Matsuda, 1988). Inward rectifiers are maximally open in the resting potential range and exhibit a marked rectification in current as the stimulus approaches or exceeds the potassium equilibrium potential. Moreover, when examined, single-channel conductances are proportional to the square root of the extracellular $\mathrm{K}^{+}$concentration and channels are blocked by $\mathrm{Cs}^{+}$. Further comparison with voltage-gated heart inward rectifiers suggests Schwann cell channels also are similar in that they are complexly gated with at least 3 closed and probably, multiple open states. However, some minor differences are observed. For example, there appears to be a shift of the Schwann cell $p_{\mathrm{o}}$ curve (Fig. $8 B$ ) towards more hyperpolarized potentials when compared with other inward rectifiers (e.g., in heart and oligodendrocytes, under similar recording conditions lacking external sodium). In addition, an unexpected result was the sensitivity of $K_{I R}$ channels to block by 4AP. To date, there have been no reports that $\mathrm{K}_{\mathrm{IR}}$ channels can be blocked by 4AP (Rudy, 1988; Castle et al., 1989 ), hinting that 4AP might work as a selective blocker of $K_{O}$ channels. Supporting this notion, Barres et al. (1988) observed no effect of 4AP (1 $\mathrm{mM}$ ) on oligodendrocyte inward rectifiers. However, in our experiments the Schwann cell $\mathrm{K}_{\mathrm{IR}}$ current proved even more sensitive to $4 \mathrm{AP}(10 \mathrm{~mm})$ than the $\mathrm{K}_{o}$ current. The difference may lie in the concentrations used.

\section{Possible functions for glial channels during development}

$K_{o}$ channels: proliferation

Chiu and Wilson (1989) have proposed that a delayed outward potassium current is linked functionally to Schwann cell proliferation in adult following nerve transection. It is tempting to speculate that the same type of potassium channel also is linked to Schwann cell proliferation during normal development. Indeed, when neonatal Schwann cells in culture are stimulated to divide, an outward rectifying potassium current is enhanced (Wilson and Chiu, 1988). Interestingly, in the present study, the decline in $\mathrm{K}_{\mathrm{O}}$ currents at the soma of developing cells correlates roughly with the known decline in proliferation measured in newborn rat sciatic nerves (Friede and Samorajski, 1968). Figure 10 compares the postnatal change in $\mathrm{K}_{\mathrm{o}}$ current from this paper (-) and Schwann cell proliferation (-- ) calculated from table 2 of Friede and Samorajski (1968).

\section{$K_{I R}$ channels: buffering of $K$ ions released during nerve activities}

It has been proposed that inward rectifiers in retinal glia (Newman, 1986) and oligodendrocytes (Barres et al., 1988) play a role in buffering $\mathrm{K}^{+}$accumulated during nerve activities. It is likely that a similar role also can be ascribed to the inward rectifiers in Schwann cells since these channels are open at the resting potential. While activity-dependent accumulation of $\mathrm{K}^{+}$ ions has not been measured in developing peripheral nerves, a significant $\mathrm{K}^{+}$accumulation following repetitive nerve stimulations has been demonstrated in developing optic nerves (Connors et al., 1982). Most interestingly, activity-dependent $\mathrm{K}^{+}$ accumulation showed a marked reduction commensurate with the onset of myelination (Connors et al., 1982). The downregulation of inward rectifiers at the soma of Schwann cells observed here may reflect a diminishing need for buffering if $\mathrm{K}^{+}$accumulation is reduced similarly in developing sciatic nerves. Presumably, both internodal and nodal regions contribute to electrogenesis during early development when myelin wrappings are few and loose. Delayed rectifying potassium channels on internodes (Chiu and Ritchie, 1980; Chiu and Schwarz, 1987) should extensively contribute to $\mathrm{K}^{+}$accumulation. As myelin 
wrappings become tighter, electrogenesis is eventually restricted to the narrow nodal regions, presumably leading to a dramatic reduction in $\mathrm{K}^{+}$rclcascd per unit volume of nerves. Whether this is functionally matched by a corresponding migration of inward rectifiers to the paranodal Schwann cell processes in mature nerves remains an open possibility.

\section{References}

Aguayo AJ, Charron L, Bray GM (1976) Potential of Schwann cells from unmyelinated nerves to produce myelin: a quantitative ultrastructural and radiographic study. J Neurocytol 5:565-573.

Barres BA, Chun LLY, Corey DP (1988) Ion channel expression by white matter glia: I. Type 2 astrocytes and oligodendrocytes. Glia 1: $10-30$.

Bray GM, Rasminsky M, Aguayo AJ (1981) Interactions between axons and their sheath cells. Annu Rev Neurosci 4:127-162.

Brown MJ, Asbury AK (1981) Schwann cell proliferation in the postnatal mouse: timing and topography. Exp Neurol 74:170-186.

Castle NA, Haylett DG, Jenkinson DH (1989) Toxins in the characterization of potassium channels. Trends Neurosci 12:59-65.

Chiu SY (1987) Sodium currents in axon-associated Schwann cells from adult rabbits. J Physiol (Lond) 386:181-203.

Chiu SY (1988) Changes in excitable membrane properties in Schwann cells of adult rabbit sciatic nerves following nerve transection. J Physiol (Lond) 396:173-188.

Chiu SY, Ritchie JM (1980) Potassium channels in nodal and internodal axonal membrane of mammalian myelinated fibre. Nature 284: $170-171$.

Chiu SY, Schwarz W (1987) Sodium and potassium currents in acutely demyelinated internodes of rabbit sciatic nerves. J Physiol (Lond) 391:631-649.

Chiu SY, Wilson GF (1989) The role of potassium channels in Schwann cell proliferation in Wallerian degeneration of explant rabbit sciatic nerves. J Physiol (Lond) 408:199-222.

Chiu SY, Shrager P, Ritchie JM (1984) Neuronal-type $\mathrm{Na}^{+}$and $\mathrm{K}^{+}$ channels in rabbit cultured Schwann cells. Nature 311:156-157.

Colquhoun D, Sigworth FJ (1983) Fitting and statistical analysis of single-channel records. In: Single-channel recording (Sakmann B, Neher E, eds), pp 191-263. New York: Plenum.

Connors BW, Ransom BR, Kunis DM, Gutnick MJ (1982) Activitydependent $K$ accumulation in the developing rat optic nerve. Science 216:1341-1343.

Friede RL, Samorajski T (1968) Myelin formation in the sciatic nerve of the rat. A quantitative electron microscopic, histochemical and radioautographic study. J Neuropathol Exp Neurol 27:546-570.

Gray PTA, Ritchie JM (1985) Ion channels in Schwann and glial cells. Trends Neurosci 8:411-415.

Hamill OP, Marty A, Neher E, Sakmann B, Sigworth F (1981) Im- proved patch-clamp techniques for high-resolution current recording from cells and cell-free membrane patches. Pfluegers Arch 391:85100.

Matsuda $H$ (1988) Open-state substructure of inwardly rectifying potassium channels revealed by magnesium block in guinea-pig heart cells. I Physiol (Lond) 397:237-258.

Matsuda H, Saigusa A, Irisawa $H$ (1987) Ohmic conductance through the inwardly rectifying $\mathrm{K}$ channel and blocking by internal $\mathrm{Mg}^{2+}$. Nature 325:156-159.

Newman EA (1985) Voltage-dependent calcium and potassium channels in retinal glial cells. Nature 317:809-811.

Rudy B (1988) Diversity and ubiquity of K channels. Neurosci 25: $729-749$.

Sakmann B, Neher E (1983) Geometric parameters of pipettes and membrane patches. In: Single-channel recording, B (Sakmann B, Neher E, eds), pp 37-51. New York: Plenum.

Sakmann B, Trube G (1984a) Conductance properties of single inwardly rectifying potassium channels in ventricular cells from guineapig heart. J Physiol (Lond) 347:641-657.

Sakmann B, Trube G (1984b) Voltage-dependent inactivation of inward-rectifying single-channel currents in the guinea-pig heart cell membrane. J Physiol (Lond) 347:659-683.

Salzer JL, Bunge RP (1980) Studies of Schwann cell proliferation. I. An analysis in tissue culture of proliferation during development, Wallerian degeneration, and direct injury. J Cell Biol 8:739-752.

Shrager P, Chiu SY, Ritchie JM (1985) Voltage-dependent sodium and potassium channels in mammalian cultured Schwann cells. Proc Natl Acad Sci USA 82:948-952.

Soliven B, Szuchet S, Arnason GW, Nelson DJ (1988) Voltage-gated potassium currents in cultured ovine oligodendrocytes. J Neurosci 8: 2131-2141.

Sontheimer H, Trotter J, Schachner M, Kettenmann H (1989) Channel expression correlates with differentiation stage during the development of oligodendrocytes from their precursor cells in culture. Neuron 2:1135-1145.

Vandenberg CA (1987) Inward rectification of a potassium channel in cardiac ventricular cells depends on internal magnesium ions. Proc Natl Acad Sci USA 84:2560-2564.

Waxman SG, Ritchie JM (1985) Organization of ion channels in the myelinated fiber. Science 228:1502-1507.

Webster, HdeF, Favilla JT (1984) Development of peripheral nerve fibers. In: Peripheral neuropathy (Dyck PJ, Thomas PK, Lambert EH, Bunge RP, eds), pp 329-359. Philadelphia: Saunders.

Weinberg HJ, Spencer PS (1976) Studies on the control of myelinogenesis. II. Evidence for neuronal regulation of myelin production. Brain Res 113:363-378.

Wilson GF, Chiu SY (1988) Effects of mitogens on Schwann cell ion channels Soc Neurosci Abstr 14:64.4.

Wood PM, Bunge RP (1975) Evidence that sensory axons are mitogenic for Schwann cells. Nature 256:662-664. 